\title{
Characteristics and Outcomes of Physician-to-Physician Telephone Consultation Programs: Environmental Scan
}

Peter George Jaminal Tian ${ }^{1}$, MSc, MD; Jeffrey Richard Harris ${ }^{2}$, MHA, MD; Hadi Seikaly ${ }^{2}$, MA, MD; Thane Chambers ${ }^{3}$, MLIS; Sara Alvarado ${ }^{1}, \mathrm{MPH}$; Dean Eurich ${ }^{4}, \mathrm{MSc}, \mathrm{PhD}$

\footnotetext{
${ }^{1}$ Department of Family Medicine, University of Alberta, Edmonton, AB, Canada

${ }^{2}$ Division of Otolaryngology, Department of Surgery, University of Alberta, Edmonton, AB, Canada

${ }^{3}$ University of Alberta Libraries, University of Alberta, Edmonton, AB, Canada

${ }^{4}$ School of Public Health, University of Alberta, Edmonton, AB, Canada
}

\section{Corresponding Author:}

Peter George Jaminal Tian, MSc, MD

Department of Family Medicine

University of Alberta

6-40 University Terrace

8303112 St NW

Edmonton, AB, T6G 2T4

Canada

Phone: 17804926306

Email: petergeo@ualberta.ca

\section{Abstract}

Background: Telephone consultations between physicians provide quick access to medical advice, allowing patients to be cared for by calling physicians in their local settings.

Objective: As part of a quality assurance study of a physician-to-physician consultation program in Alberta, Canada, this environmental scan aims to identify the characteristics and outcomes of physician-to-physician telephone consultation programs across several countries.

Methods: We searched 7 databases to identify English publications in 2007-2017 describing physician-to-physician consultations using telephones as the main technology. To identify Canadian programs, the literature search was supplemented with an additional internet search.

Results: The literature search yielded 2336 citations, of which 17 publications were included. Across 7 countries, 14 telephone consultation programs provided primary care providers with access to various specialists through hotlines, paging systems, or call centers. The programs reported on the avoidance of hospitalizations, emergency department visits and specialty visits, caller satisfaction with the telephone consultation, and cost avoidance.

Conclusions: Telephone consultation programs between health care providers have facilitated access to specialist care and prevented acute care use.

(JMIR Form Res 2021;5(2):e17672) doi: 10.2196/17672

\section{KEYWORDS}

telephone consultations; teleconsultations; remote consultations; telemedicine; eHealth; environmental scan

\section{Introduction}

Health care systems continuously evolve. At this point, a health care system's efficiency is a measure of its ability to rapidly collect, store, and analyze information and make it accessible in real time to a wide range of health care providers to optimize patient care. A key component of these systems is the use of

technology to allow health care providers to easily consult and securely share patient information with other providers. The World Health Organization (WHO) promotes this use of information communication technology (called eHealth) in support of health care services and training. In a 2016 survey, the WHO reported that $58 \%$ of responding member states had eHealth strategies, and $62 \%$ of member states had a consultation service using mobile information communication technology 
between health care practitioners or between health care practitioners and patients [1].

This ubiquitous use of technology in health care is reflected in published literature, and the benefits of these systems to care processes have been well documented. A systematic review by Deldar et al [2] found 174 publications examining the role of teleconsultations. Another systematic review by Saliba et al [3] identified 94 studies evaluating the facilitators and barriers of various telemedicine services. The delivery of such eHealth solutions is substantial. Teleconsultations in dermatology [4] and psychiatry [5], for example, may come in different modalities and be provided using videoconferencing and store-and-forward systems (ie, sending images and text information). Teleradiology, which has been around for decades, allows for the transmission, storage, and retrieval of images between radiologists and other professionals [6]. Many other technologies may be used to serve as a means of accessible electronic medical records, mobile telephone symptom recordings, and dedicated support lines, as used, for example, in palliative care [7].

In Alberta, Canada, physicians have access to telephone consultations with specialists through a 24/7 call center called RAAPID (Referral, Access, Advice, Placement, Information, and Destination). RAAPID ensures that physicians have quick access to other physicians (often specialists) for advice, allowing patients to be cared for by the calling physician in their local setting. However, if patients require transfer to other institutions for care, RAAPID also facilitates these transfers [8]. One component of the RAAPID system that has been increasingly utilized is telephone consultation with Otolaryngology-Head and Neck Surgery (OHNS). As part of a quality assurance study to evaluate RAAPID's telephone consults with OHNS, we conducted an environmental scan of similar programs in other parts of the world, searching for program characteristics and outcomes associated with similar physician-to-physician telephone consultation programs.

\section{Methods}

We used a combination of formal literature searches and internet searches based on methods adapted for the conduct of an environmental scan [9]. Other published environmental scans have also used internet searches for gathering data [10,11]. Since the RAAPID program provides consultation using only phones between physicians, we limited our search to programs that included physician-to-physician consultation with telephone as the main technology.

An information technologist (author TC) performed the literature search. The search was done on the following databases: Ovid MEDLINE(R), Embase, Cochrane Database of Systematic Reviews, Cochrane Central Register of Controlled Trials, NHS Economic Evaluation Database, CINAHL, and Web of Science
Core Collection. The search was limited to English publications in the 10-year range of 2007-2017 to ensure that identified articles reflected more contemporary practice in the field. To identify Canadian programs, the literature search was supplemented with an additional internet search (by author PT) using the following search terms in Google: (Physician or Doctor) AND (Telephone Consultation or Phone Consultation). Then we reviewed potentially relevant search results and websites. The internet search results were limited to the first 10 search result pages $(\sim 100$ results).

Three authors (PT, TC, SA) screened the search results for programs providing access to specialists through telephone consultations. For the results from the literature search, a 2-step screening was performed: title-abstract screening and full-text review to identify relevant studies. The title-abstract screening was performed independently by 2 authors (PT and TC; PT and SA). Then, full-text screening was independently reviewed by 2 authors (PT and SA). Disagreements in the screening decisions were resolved by discussion. Only consultation programs that used the telephone as the main technology were included, as well as studies that used telephones for initial consultations before using other technologies at a later time. However, consultation programs that used the telephone in combination with other technologies (such as fax, video platform, electronic communication, mobile messaging, and web-based platforms) were excluded.

One author (PT) extracted the data, and the data were verified by a second author (SA). The following data were extracted from the publications and the internet search results: the name of the program, the country within which the program operates, a description of the program, who the program is available to, the scheduled times and specialty areas in which the service is available, reported measures (ie, the volume of calls, response times), disposition after consultation (ie, sent home, sent to the emergency department or hospital, elective consultation in a specialty clinic), satisfaction with the calls, and potential costs or cost avoidance. For the supplemental internet search, one author (PT) reviewed the search results and extracted the data.

\section{Results}

\section{Literature and Internet Search}

The literature search yielded 2336 citations, of which 17 publications were identified and included (Figure 1). These 17 publications described 14 telephone consultation programs: 4 programs in the United States, 3 programs each in Canada and France, and 1 program each in Australia, the Netherlands, the United Kingdom, and Italy (Table 1). The sample sizes of the included consultation programs ranged from 19 to 4436 . In addition to these publications, the internet search yielded 17 webpages linked to 13 Canadian telephone consultation programs (Table 2). 
Figure 1. Flow chart of the literature review process.

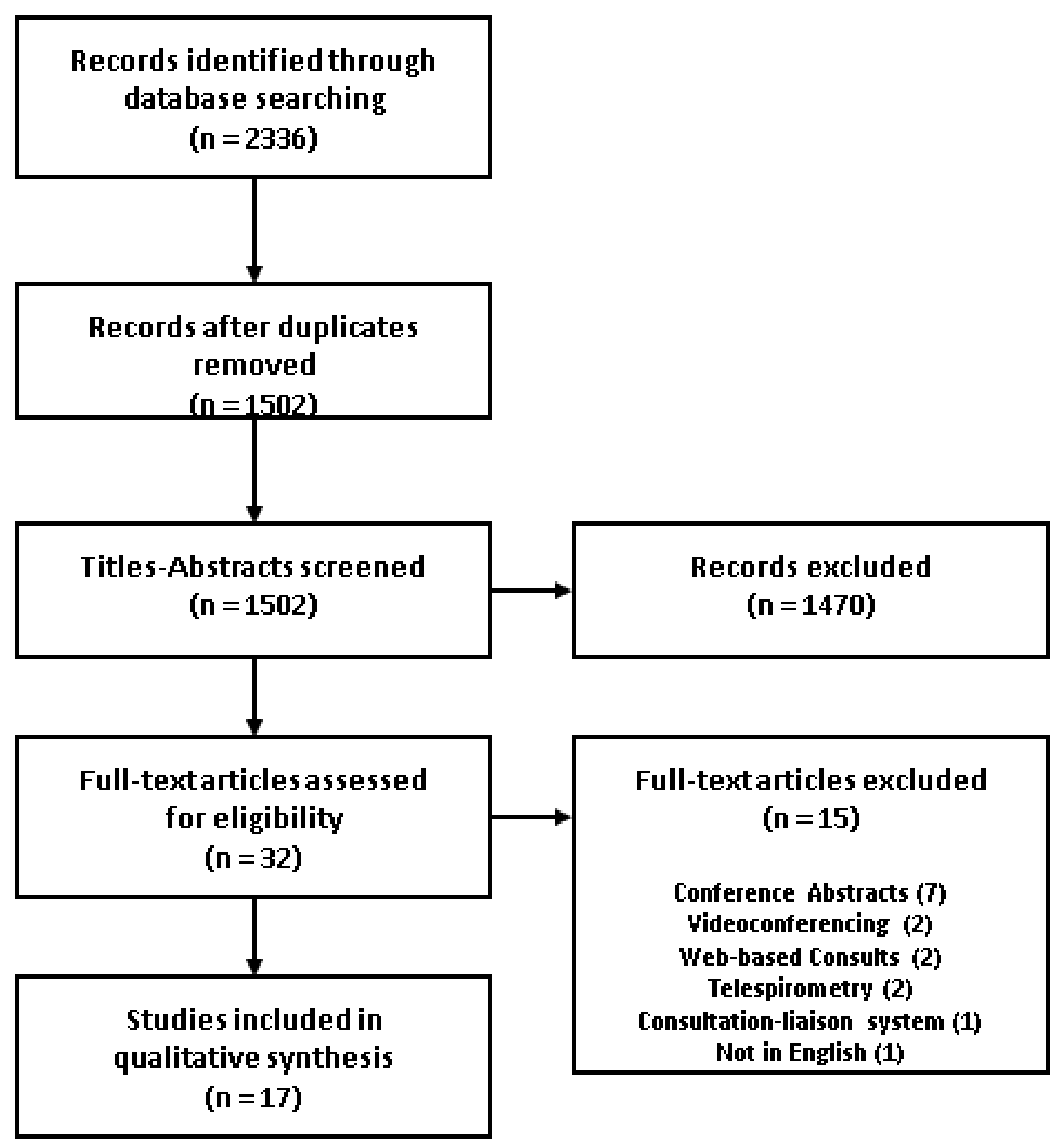


Table 1. Characteristics of telephone consultation programs $(n=14)$.

\begin{tabular}{|c|c|c|c|c|c|}
\hline $\begin{array}{l}\text { Publication (first au- } \\
\text { thor, publication year, } \\
\text { country) }\end{array}$ & $\begin{array}{l}\text { Program name or de- } \\
\text { scription }\end{array}$ & $\begin{array}{l}\text { Access } \\
\text { schedule }\end{array}$ & $\begin{array}{l}\text { Physician seeking consul- } \\
\text { tation }\end{array}$ & $\begin{array}{l}\text { Physician providing consultation } \\
\text { (number of calls and duration) }\end{array}$ & $\begin{array}{l}\text { Post-call patient dis- } \\
\text { position }\end{array}$ \\
\hline Bal, 2011, France. & $\begin{array}{l}\text { Hotline on a dedicated } \\
\text { cellular telephone }\end{array}$ & $\begin{array}{l}24 \text { hours per } \\
\text { day, } 7 \text { days } \\
\text { per week }\end{array}$ & General practitioner & $\begin{array}{l}\text { Infectious disease resident and } \\
\text { specialist } \\
\text { ( } 284 \text { calls in } 6 \text { months) }\end{array}$ & $-^{\mathrm{a}}$ \\
\hline Clark, 2015, Canada. & $\begin{array}{l}\text { Randomized trial } \\
\text { comparing usual care } \\
\text { with telephone consult }\end{array}$ & - & Primary care physician & $\begin{array}{l}\text { Pain specialist at } 0 \text { months, } 3 \\
\text { months, and } 6 \text { months }(n=41)\end{array}$ & - \\
\hline Hilt, 2013, US. & $\begin{array}{l}\text { The Partnership Ac- } \\
\text { cess Line (toll-free } \\
\text { number) }\end{array}$ & $\begin{array}{l}8 \text { AM-5 PM, } \\
\text { Monday-Fri- } \\
\text { day }\end{array}$ & Primary care provider & $\begin{array}{l}\text { Child and adolescent psychiatrist } \\
\text { ( } 2285 \text { calls in } 37 \text { months) }\end{array}$ & - \\
\hline $\begin{array}{l}\text { Hobbs, 2014, US; } \\
\text { Sarvet, 2011, US; } \\
\text { Sarvet, 2010, US; } \\
\text { Straus, 2014, US. }\end{array}$ & $\begin{array}{l}\text { Massachusetts Child } \\
\text { Psychiatry Access } \\
\text { Hotline (answered by } \\
\text { the care coordinator } \\
\text { and routed to an appro- } \\
\text { priate team member) }\end{array}$ & $\begin{array}{l}\text { Business } \\
\text { hours, Mon- } \\
\text { day-Friday }\end{array}$ & $\begin{array}{l}\text { Pediatric primary care } \\
\text { clinician (eg, pediatri- } \\
\text { cian, family practice } \\
\text { physician, nurse practi- } \\
\text { tioner) }\end{array}$ & $\begin{array}{l}\text { Child psychiatrist, family psy- } \\
\text { chotherapist, care coordinator } \\
\text { ( } 4436 \text { calls in } 1 \text { year) }\end{array}$ & $\begin{array}{l}24 \%(1974 / 8223) \text { of } \\
\text { consults resulted in } \\
\text { the primary care } \\
\text { clinician maintain- } \\
\text { ing primary clinical } \\
\text { responsibility }\end{array}$ \\
\hline Lear, 2010, Canada. & $\begin{array}{l}\text { Rapid Access to Cardi- } \\
\text { ology Expertise (pilot } \\
\text { project for Wilson, } \\
2016 \text {, Canada, listed } \\
\text { below; paging system } \\
\text { which initiates a call) }\end{array}$ & Business day & Family physician & $\begin{array}{l}\text { Cardiologist } \\
\text { (118 calls in } 7 \text { month); the cardiol- } \\
\text { ogist calls the paging family } \\
\text { physician }\end{array}$ & $\begin{array}{l}17.8 \% \text { of consults } \\
\text { resulted in further } \\
\text { consultation with the } \\
\text { cardiologist }\end{array}$ \\
\hline Linklater, 2009, UK. & Telephone advice line & $\begin{array}{l}24 \text { hours per } \\
\text { day, } 7 \text { days } \\
\text { per week }\end{array}$ & $\begin{array}{l}\text { Primary care clinician } \\
\text { (eg, general practitioner, } \\
\text { hospital doctor, hospi- } \\
\text { tal/community nurse, pa- } \\
\text { tient or carer) }\end{array}$ & $\begin{array}{l}\text { Consultant or specialist registrar } \\
\text { in palliative medicine } \\
\text { ( } 1146 \text { calls in } 6 \text { years and } 1 \text { month) }\end{array}$ & - \\
\hline Marquet, 2013, France. & $\begin{array}{l}\text { National network of } \\
\text { infectious disease ex- } \\
\text { perts }\end{array}$ & - & $\begin{array}{l}\text { Community and health } \\
\text { care professional }\end{array}$ & $\begin{array}{l}\text { Infectious disease specialist } \\
\text { (323 calls in } 5 \text { days) }\end{array}$ & $\begin{array}{l}6 \% \text { of consults led to } \\
\text { infectious disease } \\
\text { consultation; } 5.5 \% \\
\text { led to hospitalization }\end{array}$ \\
\hline Salles, 2014, France. & Hotline & $\begin{array}{l}9 \text { AM-7 PM, } \\
\text { Monday-Fri- } \\
\text { day }\end{array}$ & General practitioner & $\begin{array}{l}\text { Geriatrician ( } 714 \text { calls in } 16 \\
\text { months) }\end{array}$ & $\begin{array}{l}38.3 \% \text { of consults } \\
\text { resulted in advice; } \\
5.3 \% \text { resulted in } \\
\text { geriatric consulta- } \\
\text { tion; } 9.2 \% \text { resulted } \\
\text { in a hospital day vis- } \\
\text { it; } 42.9 \% \text { resulted in } \\
\text { hospitalization in the } \\
\text { geriatrics ward; } \\
4.3 \% \text { resulted in di- } \\
\text { rect admission to the } \\
\text { emergency depart- } \\
\text { ment }\end{array}$ \\
\hline $\begin{array}{l}\text { Sankaranarayanan, } \\
\text { 2010, Australia. }\end{array}$ & Telephone line & $\begin{array}{l}12 \text { PM-1 } \\
\text { PM, Mon- } \\
\text { day-Friday }\end{array}$ & General practitioner & $\begin{array}{l}\text { Psychiatrist } \\
\text { (19 discussions in } 3 \text { months) }\end{array}$ & - \\
\hline $\begin{array}{l}\text { van Heest, 2008, } \\
\text { Netherlands. }\end{array}$ & Telephone line & $\begin{array}{l}24 \text { hours per } \\
\text { day, } 7 \text { days } \\
\text { per week }\end{array}$ & $\begin{array}{l}\text { Health care provider (eg, } \\
\text { general practitioner, } \\
\text { nurse, pharmacist, other } \\
\text { health care provider) }\end{array}$ & $\begin{array}{l}\text { General practitioner adviser in } \\
\text { palliative care on treating nausea } \\
\text { and vomiting ( } 572 \text { consultations } \\
\text { in } 1 \text { year) }\end{array}$ & - \\
\hline Waldura, 2013, US. & HIV Warmline & 9 AM-8 PM & $\begin{array}{l}\text { Primary care clinician } \\
\text { (eg, physician, other } \\
\text { health care provider) }\end{array}$ & $\begin{array}{l}\text { HIV specialist (eg, physician, } \\
\text { pharmacist) }\end{array}$ & - \\
\hline
\end{tabular}




\begin{tabular}{|c|c|c|c|c|c|}
\hline $\begin{array}{l}\text { Publication (first au- } \\
\text { thor, publication year, } \\
\text { country) }\end{array}$ & $\begin{array}{l}\text { Program name or de- } \\
\text { scription }\end{array}$ & $\begin{array}{l}\text { Access } \\
\text { schedule }\end{array}$ & $\begin{array}{l}\text { Physician seeking consul- } \\
\text { tation }\end{array}$ & $\begin{array}{l}\text { Physician providing consultation } \\
\text { (number of calls and duration) }\end{array}$ & $\begin{array}{l}\text { Post-call patient dis- } \\
\text { position }\end{array}$ \\
\hline Wegner, 2008, US. & Telephone line & - & Primary care physician & $\begin{array}{l}\text { Pediatric subspecialist (306 con- } \\
\text { sults in } 8 \text { months) }\end{array}$ & $\begin{array}{l}32 \% \text { of consults } \\
\text { avoided a PS }{ }^{\text {b }} \text { visit; } \\
11 \% \text { avoided a hospi- } \\
\text { tal transfer; } 5 \% \\
\text { avoided a hospital } \\
\text { admission; } 5 \% \\
\text { avoided an emergen- } \\
\text { cy department visit }\end{array}$ \\
\hline Wilson, 2016, Canada. & $\begin{array}{l}\text { Rapid Access to Con- } \\
\text { sultative Expertise } \\
\text { (hotline that automati- } \\
\text { cally routes to a spe- } \\
\text { cialist's pager/mobile } \\
\text { phone) }\end{array}$ & $\begin{array}{l}8 \mathrm{AM}-5 \\
\text { PM, Mon- } \\
\text { day-Friday }\end{array}$ & $\begin{array}{l}\text { Family physician or } \\
\text { nurse practitioner }\end{array}$ & $\begin{array}{l}\text { Various specialists (a subset of } \\
2000 \text { calls in } 2 \text { years) }\end{array}$ & $\begin{array}{l}60 \% \text { of consults pre- } \\
\text { vented a face-to-face } \\
\text { consultation; } 32 \% \\
\text { prevented an emer- } \\
\text { gency department } \\
\text { visit }\end{array}$ \\
\hline Zanaboni, 2009, Italy. & $\begin{array}{l}\text { Telephone calls rout- } \\
\text { ed through a service } \\
\text { center; for specific } \\
\text { consultations, callers } \\
\text { were invited to use } \\
\text { biomedical devices } \\
\text { for specific consulta- } \\
\text { tions }\end{array}$ & - & General practitioner & $\begin{array}{l}\text { Cardiologist, dermatologist, or di- } \\
\text { abetologist } \\
\text { (927 cardiology calls in } 25 \\
\text { months) }\end{array}$ & $\begin{array}{l}8 \% \text { of consults result- } \\
\text { ed in an emergency } \\
\text { department visit or } \\
\text { hospitalization; } 1 \% \\
\text { resulted in an in- } \\
\text { clinic visit; } 77 \% \\
\text { avoided an emergen- } \\
\text { cy department visit, } \\
\text { hospitalization, or an } \\
\text { in-clinic consult }\end{array}$ \\
\hline
\end{tabular}

a__: not available.

${ }^{\mathrm{b}} \mathrm{PS}$ : pediatric subspecialist. 
Table 2. Characteristics of Canadian physician-to-physician telephone consultation programs yielded from an internet search ( $\mathrm{n}=13$ ).

\begin{tabular}{|c|c|c|c|c|}
\hline Program Name & Province & Program description & Physician seeking consultation & $\begin{array}{l}\text { Physician providing consul- } \\
\text { tation }\end{array}$ \\
\hline Cancer Line & Alberta & $\begin{array}{l}\text { Assists with cancer-related ques- } \\
\text { tions }\end{array}$ & $\begin{array}{l}\text { Physician or other health care } \\
\text { provider }\end{array}$ & $\begin{array}{l}\text { Medical or radiation oncolo- } \\
\text { gist, or expert oncology } \\
\text { nurse }\end{array}$ \\
\hline $\begin{array}{l}\text { Orthopedic Consult } \\
\text { Line }\end{array}$ & Alberta (Edmonton) & $\underline{-a}^{\mathrm{a}}$ & - & - \\
\hline $\begin{array}{l}\text { PaedLink Telephone } \\
\text { Consultation Service }^{\mathrm{b}}\end{array}$ & Alberta (Calgary) & $\begin{array}{l}\text { Single access number; accessible } \\
\text { from } 8 \text { AM- } 8 \text { PM, Monday-Sun- } \\
\text { day }\end{array}$ & - & - \\
\hline $\begin{array}{l}\text { Referral, Access, Ad- } \\
\text { vice, Placement, Infor- } \\
\text { mation, and Destina- } \\
\text { tion (RAAPID) }\end{array}$ & Alberta & $\begin{array}{l}\text { Hotline accessible } 24 \text { hours per } \\
\text { day, } 7 \text { days per week }\end{array}$ & Physician & Multiple specialists \\
\hline Specialist LINK $^{\mathrm{b}}$ & Alberta (Calgary) & $\begin{array}{l}\text { Telephone advice for nonurgent } \\
\text { cases; accessible from } 8 \text { AM-5 } \\
\text { PM, Monday-Friday, except on } \\
\text { statutory holidays }\end{array}$ & $\begin{array}{l}\text { Physician, nurse practitioner, mid- } \\
\text { wife, pediatrician }\end{array}$ & Multiple specialists \\
\hline $\begin{array}{l}\text { Rapid Access to Con- } \\
\text { sultative Expertise }\end{array}$ & $\begin{array}{l}\text { British Columbia, } \\
\text { Yukon }\end{array}$ & $\begin{array}{l}\text { Accessible from } 8 \text { AM-5 PM, } \\
\text { Monday-Friday }\end{array}$ & Physician, nurse practitioner & Multiple specialists \\
\hline $\begin{array}{l}\text { Rapid Access to Con- } \\
\text { sultative Expertise }\end{array}$ & Manitoba & - & - & - \\
\hline Med-Response & $\begin{array}{l}\text { North West Territo- } \\
\text { ries }\end{array}$ & - & - & - \\
\hline CritiCall-Ontario & Ontario & - & - & - \\
\hline Ontario Shores & Ontario & Telephone advice; online booking & $\begin{array}{l}\text { Family physician, nurse practition- } \\
\text { er }\end{array}$ & Psychiatrist \\
\hline \multirow[t]{2}{*}{$\begin{array}{l}\text { Leveraging Immediate } \\
\text { Non-urgent Knowl- } \\
\text { edge (LINK) }\end{array}$} & Saskatchewan & $\begin{array}{l}\text { Physician-to-physician telephone } \\
\text { consultation service for nonurgent } \\
\text { conditions; accessible from }\end{array}$ & - & Multiple specialists \\
\hline & & 8 AM-5 PM, Monday-Friday & & \\
\hline $\begin{array}{l}\text { Acute Care Access } \\
\text { Line (ACAL) }\end{array}$ & Saskatchewan & $\begin{array}{l}\text { Urgent calls; complementary to } \\
\text { LINK service }\end{array}$ & - & - \\
\hline Bedline & Saskatchewan & - & - & - \\
\hline
\end{tabular}

a__: not available.

${ }^{\mathrm{b}}$ Eligible for continuing medical education (CME) credits.

\section{Telephone Consultation Process}

The process starts with the provision of a telephone line. Some publications used the term hotline; however, since no reported definitions of a hotline differentiate it from a regular telephone line, we extracted the terms as published. Of the 17 included studies, 10 reported a program in which the call connects and is answered directly by the specialist [12-21], 4 indicated programs in which the call is answered by an intermediary who then routes the call to the specialist [22-25], and 2 indicated that the call is routed to a specialist's pager or mobile messaging service, requiring the specialist to respond with a call to the physician (Figure 2) [26,27]. 
Figure 2. Various telephone consultation processes.

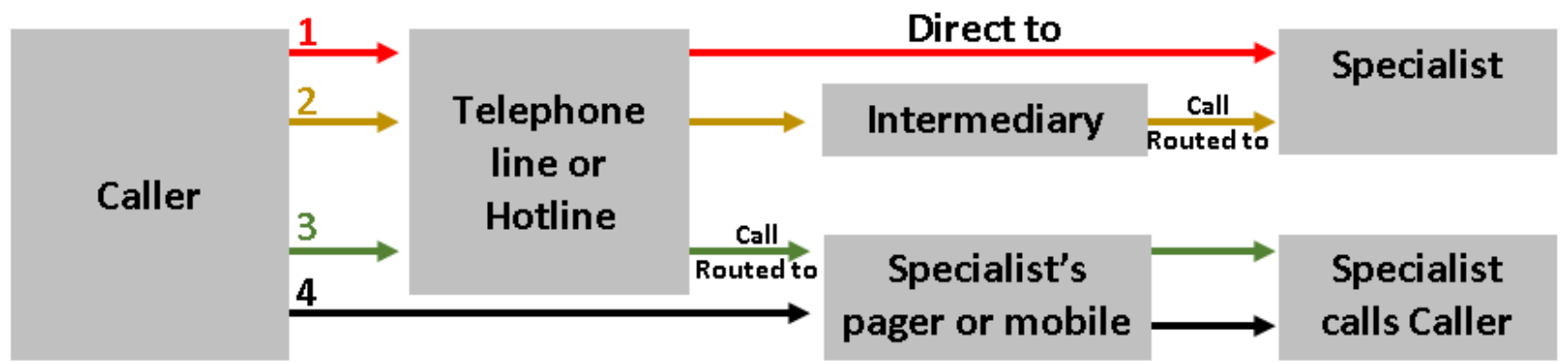

\section{Accessibility}

The accessibility of telephone consultations varied. Some were available 24 hours a day, 7 days a week [12,15]. Others were only available during business hours or extended business hours, Mondays to Fridays [13,16,22,26,27]. One program was limited to 1 hour a day, 5 days a week [14].

Response time between the programs also varied. Wilson [27] reported that $78 \%$ of calls were responded to within 10 minutes. Lear [26] reported that $81.4 \%$ of calls were returned within 1 hour or less. These 2 studies used a system where providers paged specialists who called them back. Marquet [28] reported that $19.8 \%$ of calls were answered immediately.

\section{Callers}

Most of the programs were geared toward family physicians, general practitioners, or primary care providers [12-15,19,24,26,27]. In addition to physician callers, some programs also had nonphysician callers: nurse practitioners, pharmacists, and other professionals [15,16,27,28]. Other programs were highly restricted, such as the Massachusetts Child Psychiatry Access, which was limited to pediatric primary care clinicians like pediatricians, nurse practitioners, and family physicians [21-23].

\section{Consulted Specialists}

The different programs offered consults with different specialties. The Rapid Access to Consultative Expertise (RACE) in British Columbia offered access to a wide number of specialists [27]. However, the majority of the studies reported consults with only certain physician specialists, namely, psychiatrists [14,22], infectious disease specialists [12,28], geriatricians [13], pediatricians [17,22], and cardiologists $[24,26]$. One reported access to general practitioners who served as advisers [15]. Others provided access to nonphysician members of the team, such as pharmacists, psychotherapists, or care coordinators [16,22].

\section{Patient Disposition}

Only $6(35 \%)$ of the 17 publications assessed any type of disposition within the program. With respect to patient and medical advice, only 1 publication explicitly noted this feature. Salles [13] reported that $38.3 \%$ resulted in advice. Although Hobbs [22] did not report this, another publication reported that in the Massachusetts Child Psychiatry Access program, 24\% of consults resulted in the primary care clinician maintaining primary care responsibility [21]. Several publications noted that additional consultation occurred as a result of the call. Lear [26] reported that $17.8 \%$ resulted in further consultation with the cardiologist. Marquet [28] reported that $6 \%$ led to infectious disease consultation. Salles [13] reported that 5.3\% resulted in geriatric consultation. Wegner [17] reported that $32 \%$ avoided pediatric subspecialists' visits. Wilson [27] reported that $60 \%$ prevented a face-to-face consultation. Several publications $(5 / 17$, $29 \%$ ) assessed emergency department visits or hospitalization as an outcome of the program $[13,17,24,27,28]$. However, the studies differed in how the patient dispositions were reported. Zanaboni [24] reported that $8 \%$ resulted in emergency department visits or hospitalization. Marquet [28] reported that $5.5 \%$ led to hospitalization. Salles [13] reported that $9.2 \%$ resulted in a hospital day visit, $42.9 \%$ resulted in hospitalization or a visit to a geriatrics ward, and $4.3 \%$ in a direct emergency department admission [13]. Conversely, several publications noted large effects with respect to avoidance of emergency department visits or hospitalizations. Indeed, Zanaboni [24] reported that $77 \%$ of calls avoided emergency department visits or hospitalizations. Wilson [27] reported that 32\% avoided emergency department visits, while Wegner [17] reported that $5 \%$ avoided emergency department visits and 5\% avoided hospital admissions.

\section{Cost Avoidance}

Cost avoidance from the telephone consultations was reported in 3 of 17 publications (18\%) and varied depending on how the studies determined cost avoidance. Wegner [17] reported cost savings of $\$ 477,274$ for 306 consults over 8 months. These cost savings included subspecialist visit and telephone consultation costs, as well as potential costs from avoided hospitalizations. Wilson [27] reported cost savings of $\$ 9005$ for 148 calls. Zanaboni [24] reported $€ 20,472$ of direct savings for in-clinic visits for 927 calls [24].

\section{Satisfaction With Calls}

Of the 17 publications, 9 (53\%) determined satisfaction levels after the telephone consultations. Physicians rated the telephone consultations positively, ranging from $80 \%-100 \%$ [12,24,26]. The ratings comprised satisfaction with the specialist's recommendations, whether issues were addressed adequately, and improved confidence in managing patients. Also, compliance to recommendations were rated high, ranging from $90 \%-93 \%[12,15,24]$. 


\section{Discussion}

Our environmental scan identified 17 studies on telephone consultation programs between health care practitioners, and 13 programs across Canada. Programs were widely dispersed across a wide range of specialties and disease states. Overall, the most common model for accessing care was having the physician connect directly with the specialist or consultant rather than using a routing system or call-back procedure. The majority of programs were for physicians; however, many were supportive of calls from other members of the care team.

Interestingly, less than half of the publications evaluated outcomes related to patients' dispositions or costs. In the few studies that evaluated health care utilization, all reported an avoidance in either emergency department visits or hospitalizations. As expected, this translated into major cost savings for the programs. However, it is relatively unclear what the overall net savings and costs of these programs were, as few (if any) analyses accounted for the input costs of operating and maintaining these programs. Indeed, British Columbia's RACE program [27] has a low operating cost. It provides a hotline system that directly pages a specialist who, in turn, calls the referring physician. RACE reports a cost of only \$120/month for the telephone system support and an administrative support cost for 1 day per month. Costs savings and some costs occurrence to the system would be expected; however, the benefits to patients in terms of timely medical advice and indirect cost savings (eg, travel to the emergency department, time away from work) would likely offset any cost occurrences. Coupled with reduced pressure on the emergency department and hospital system reported by the programs, the benefits are likely substantial.

RAAPID's 24/7 call center shares some similarities to other telephone programs, but also notable differences. Unlike most programs that involve direct calling to specialists, physicians call a hotline and the call center connects them to specialists, if needed. The call center provides extensive support. At the consultation level, the call center triages the call to specialists, ascertains that the consultation occurred, and provides logistical support during and after the consultation. At a system level, the call center, when required, coordinates the transfer of patients to appropriate centers, with due consideration to bed management. However, this labor-intensive process impacts the operating cost (ie, the cost from 24/7 staffing).

Although more expensive to implement, the RAAPID program has previously reported that from November 2014 to October 2015 , of 51,171 telephone consultations, $36 \%$ were not referred to the emergency department $(29.1 \%$ resulted in the provision of advice and $6.9 \%$ were referred to a specialist clinic) [29]. This coincides with the figures observed in other programs reported in this paper. British Columbia's RACE reported a $32 \%$ prevention rate in emergency department visits [27]. Wegner's study [17] on pediatric subspecialist consultations reported that $52 \%$ avoided emergency department visits, specialty visits, and hospital transfers and admissions. Zanaboni's study [24] on consultation calls to cardiology, dermatology, and diabetology reported that $77 \%$ avoided emergency department visits, hospitalizations, or in-clinic consults.

This environmental scan is the first narrative review of telephone consultation programs. We have reviewed the published literature and performed a supplemental internet search. However, the heterogeneity of programs and outcome measures limited comparison across programs. Moreover, limitations in resources have precluded a systematic review and a more extensive review of internet searches. The pervasive use of technology in health care consultations was evident in the literature search and internet search. The use of phones for consultations was minor compared to the use of more recent technologies like videoconferencing, mobile messaging, and other electronic and web-based platforms.

\section{Conclusion}

Telephone consultation programs between health care providers have facilitated access to specialists. The programs have allowed primary care providers to retain the care for their patients while avoiding patient use of acute care resources. These telephone consultation programs, along with newer technologies, have increased the efficiency of health care.

\section{Conflicts of Interest}

This study received funding from the Alberta Head and Neck Centre for Oncology and Reconstruction (AHNCOR) Foundation.

\section{References}

1. World Health Organization. Global diffusion of eHealth: making universal health coverage achievable. Report of the third global survey on eHealth. Geneva: World Health Organization; 2016. URL: https://www.who.int/goe/publications/ global_diffusion/en/ [accessed 2019-05-24]

2. Deldar K, Bahaadinbeigy K, Tara SM. Teleconsultation and Clinical Decision Making: a Systematic Review. Acta Inform Med 2016 Jul 16;24(4):286-292 [FREE Full text] [doi: 10.5455/aim.2016.24.286-292] [Medline: 27708494]

3. Saliba V, Legido-Quigley H, Hallik R, Aaviksoo A, Car J, McKee M. Telemedicine across borders: a systematic review of factors that hinder or support implementation. Int J Med Inform 2012 Dec;81(12):793-809. [doi: 10.1016/i.ijmedinf.2012.08.003] [Medline: 22975018]

4. Bashshur RL, Shannon GW, Tejasvi T, Kvedar JC, Gates M. The Empirical Foundations of Teledermatology: A Review of the Research Evidence. Telemed J E Health 2015 Dec;21(12):953-979 [FREE Full text] [doi: 10.1089/tmj.2015.0146] [Medline: 26394022] 
5. Butler TN, Yellowlees P. Cost analysis of store-and-forward telepsychiatry as a consultation model for primary care. Telemed J E Health 2012;18(1):74-77. [doi: 10.1089/tmj.2011.0086] [Medline: 22085113]

6. Bashshur RL, Krupinski EA, Thrall JH, Bashshur N. The Empirical Foundations of Teleradiology and Related Applications: A Review of the Evidence. Telemed J E Health 2016 Nov;22(11):868-898 [FREE Full text] [doi: 10.1089/tmj.2016.0149] [Medline: 27585301]

7. Kidd L, Cayless S, Johnston B, Wengstrom Y. Telehealth in palliative care in the UK: a review of the evidence. J Telemed Telecare 2010;16(7):394-402. [doi: 10.1258/jtt.2010.091108] [Medline: 20813893]

8. Rohl E. RAAPID navigates coordinated care: Provincial service connects physicians with specialists, and patients with beds. Access Improvement. URL: https://www.albertahealthservices.ca/assets/info/hp/arp/if-hp-arp-raapid-care.pdf [accessed 2019-05-24]

9. Diouf NT, Menear M, Robitaille H, Painchaud GG, Légaré F. Training health professionals in shared decision making: Update of an international environmental scan. Patient Educ Couns 2016 Jun 14 [FREE Full text] [doi: 10.1016/j.pec.2016.06.008] [Medline: 27353259]

10. Leiva Portocarrero ME, Garvelink MM, Becerra Perez MM, Giguère A, Robitaille H, Wilson BJ, et al. Decision aids that support decisions about prenatal testing for Down syndrome: an environmental scan. BMC Med Inform Decis Mak 2015 Sep 24;15:76 [FREE Full text] [doi: 10.1186/s12911-015-0199-6] [Medline: 26404088]

11. Griffith L, Sohel N, Walker K, Jiang Y, Mao Y, Hopkins D, et al. Consumer products and fall-related injuries in seniors. Can J Public Health 2012 Jul 18;103(5):e332-e337. [Medline: 23617983]

12. Bal G, Sellier E, Gennai S, Caillis M, François P, Pavese P. Infectious disease specialist telephone consultations requested by general practitioners. Scand J Infect Dis 2011 Dec;43(11-12):912-917. [doi: 10.3109/00365548.2011.598874] [Medline: 21867475]

13. Salles N, Floccia M, Videau M, Diallo L, Guérin D, Valentin V, et al. Avoiding emergency department admissions using telephonic consultations between general practitioners and hospital geriatricians. J Am Geriatr Soc 2014 Apr;62(4):782-784. [doi: 10.1111/jgs.12757] [Medline: 24731033]

14. Sankaranarayanan A, Allanson K, Arya DK. What do general practitioners consider support? Findings from a local pilot initiative. Aust J Prim Health 2010;16(1):87-92. [doi: 10.1071/py09040] [Medline: 21133304]

15. van Heest F, Finlay I, van der Ven I, Otter R, Meyboom-de JB. Dutch GPs get 24-hour telephone advice on how to treat nausea and vomiting. European Journal of Palliative Care 2008;15(6):294-298 [FREE Full text] [doi:

$10.1201 / 9781785230479-21]$

16. Waldura JF, Neff S, Dehlendorf C, Goldschmidt RH. Teleconsultation improves primary care clinicians' confidence about caring for HIV. J Gen Intern Med 2013 Jun;28(6):793-800 [FREE Full text] [doi: 10.1007/s11606-013-2332-5] [Medline: 23371417]

17. Wegner SE, Humble CG, Feaganes J, Stiles AD. Estimated savings from paid telephone consultations between subspecialists and primary care physicians. Pediatrics 2008 Dec;122(6):e1136-e1140. [doi: 10.1542/peds.2008-0432] [Medline: 19047214]

18. Hilt RJ, Romaire MA, McDonell MG, Sears JM, Krupski A, Thompson JN, et al. The Partnership Access Line: evaluating a child psychiatry consult program in Washington State. JAMA Pediatr 2013 Feb;167(2):162-168. [doi: 10.1001/2013.jamapediatrics.47] [Medline: 23247331]

19. Clark AJ, Taenzer P, Drummond N, Spanswick CC, Montgomery LS, Findlay T, et al. Physician-to-physician telephone consultations for chronic pain patients: A pragmatic randomized trial. Pain Res Manag 2015;20(6):288-292 [FREE Full text] [doi: 10.1155/2015/345432] [Medline: 26474380]

20. Linklater G, Lawton S, Macaulay L, Carroll D. Palliative patients with pain: Why the family physician phones a specialist advice line. In J Disabil Hum Dev 2009;8(1):21-24. [doi: 10.1515/ijdhd.2009.8.1.21]

21. Sarvet B, Gold J, Bostic JQ, Masek BJ, Prince JB, Jeffers-Terry M, et al. Improving access to mental health care for children: the Massachusetts Child Psychiatry Access Project. Pediatrics 2010 Dec;126(6):1191-1200. [doi: 10.1542/peds.2009-1340] [Medline: 21059722]

22. Hobbs Knutson K, Masek B, Bostic JQ, Straus JH, Stein BD. Clinicians' utilization of child mental health telephone consultation in primary care: findings from Massachusetts. Psychiatr Serv 2014 Mar 01;65(3):391-394. [doi: 10.1176/appi.ps.201200295] [Medline: 24584527]

23. Sarvet B, Gold J, Straus JH. Bridging the divide between child psychiatry and primary care: the use of telephone consultation within a population-based collaborative system. Child Adolesc Psychiatr Clin N Am 2011 Jan;20(1):41-53. [doi: 10.1016/j.chc.2010.08.009] [Medline: 21092911]

24. Zanaboni P, Scalvini S, Bernocchi P, Borghi G, Tridico C, Masella C. Teleconsultation service to improve healthcare in rural areas: acceptance, organizational impact and appropriateness. BMC Health Serv Res 2009 Dec 18;9:238 [FREE Full text] [doi: 10.1186/1472-6963-9-238] [Medline: 20021651]

25. Straus JH, Sarvet B. Behavioral health care for children: the massachusetts child psychiatry access project. Health Aff (Millwood) 2014 Dec;33(12):2153-2161. [doi: 10.1377/hlthaff.2014.0896] [Medline: 25489033]

26. Lear SA, MacKinnon D, Farias-Godoy A, Nasmith J, Mazowita G, Ignaszewski A. Rapid access to cardiology expertise: an innovative program to provide telephone support for family physicians. Healthc Q 2010;13(4):56-60. [doi:

$\underline{10.12927 / \text { hcq. 2013.21999] [Medline: 24953810] }}$ 
27. Wilson M, Mazowita G, Ignaszewski A, Levin A, Barber C, Thompson D, et al. Family physician access to specialist advice by telephone: Reduction in unnecessary specialist consultations and emergency department visits. Can Fam Physician 2016 Nov;62(11):e668-e676 [FREE Full text] [Medline: 28661886]

28. Marquet A, Ollivier F, Boutoille D, Thibaut S, Potel G, Ballereau F. A national network of infectious diseases experts. Médecine et Maladies Infectieuses 2013 Dec;43(11-12):475-480. [doi: 10.1016/j.medmal.2013.09.005]

29. Montpetit J, Burke D, Carlson K. DTN - Interfacing with RAAPID. Door-to-Needle Initiative, Quality Improvement Clinical Research, University of Calgary, Calgary, AB. URL: https://cumming.ucalgary.ca/sites/default/files/teams/239/QI_DTN/ LS2/dtn-raapid-presentation.pdf [accessed 2021-02-10]

\title{
Abbreviations \\ OHNS: Otolaryngology-Head and Neck Surgery \\ RAAPID: Referral, Access, Advice, Placement, Information, and Destination \\ RACE: Rapid Access to Consultative Expertise \\ WHO: World Health Organization
}

\author{
Edited by G Eysenbach; submitted 07.01.20; peer-reviewed by E Krupinski, T Abdulai, T Aslanidis; comments to author 10.03.20; \\ revised version received 04.05.20; accepted 17.01.21; published 23.02.21 \\ Please cite as: \\ Tian PGJ, Harris JR, Seikaly H, Chambers T, Alvarado S, Eurich D \\ Characteristics and Outcomes of Physician-to-Physician Telephone Consultation Programs: Environmental Scan \\ JMIR Form Res 2021;5(2):e17672 \\ URL: https://formative.jmir.org/2021/2/e17672 \\ doi: $10.2196 / 17672$ \\ PMID: $\underline{3620325}$
}

CPeter George Jaminal Tian, Jeffrey Richard Harris, Hadi Seikaly, Thane Chambers, Sara Alvarado, Dean Eurich. Originally published in JMIR Formative Research (http://formative.jmir.org), 23.02.2021. This is an open-access article distributed under the terms of the Creative Commons Attribution License (https://creativecommons.org/licenses/by/4.0/), which permits unrestricted use, distribution, and reproduction in any medium, provided the original work, first published in JMIR Formative Research, is properly cited. The complete bibliographic information, a link to the original publication on http://formative.jmir.org, as well as this copyright and license information must be included. 